\title{
PENGARUH KONFLIK KERJA, KARAKTERISTIK INDIVIDU DAN DISIPLIN KERJA TERHADAP EFEKTIVITAS KERJA PEGAWAI DI BADAN PENANGGULANGAN BENCANA DAERAH PROVINSI SUMATERA UTARA
}

\author{
${ }^{1}$ Fahruddin, ${ }^{2}$ Lisman Saragih, ${ }^{3}$ Rajid Yuliawan, ${ }^{4}$ Rahmalinda, ${ }^{5}$ Ismail Nasution \\ ${ }_{1,2,3,4,5}$ Universitas Islam Sumatera Utara \\ Ifahruddin.mm@gmail.com, ${ }^{2}$ lisman.saragih@gmail.com, ${ }^{3}$ rajid.yuliawan@gmail.com, ${ }^{4}$ rahma.linda@gmail.com, \\ ${ }^{5}$ ismail.nasution@fe.uisu.ac.id
}

\begin{abstract}
The effectiveness of work needs to be considered because it has a great effect on the interests of the organization. Effectiveness means that a pre-planned goal can be achieved or in other words the goal achieved due to the activity process. Effectiveness can also be viewed so that the implementation of administration more achieves the results as planned, achieves the goals to be achieved and more successfully useful or appropriate. The purpose of this study was to find out the influence of work conflicts, individual characteristics, and work disciplines on the effectiveness of employee work in the Regional Disaster Management Agency of North Sumatra Province. This study uses an associative approach, which is research conducted to find out the influence or relationship between free variables and bound variables. The results showed that partial work conflicts had a significant influence on the effectiveness of employee work. Partially, individual characteristics have a significant influence on the effectiveness of employee work. Partially discipline has a significant influence on the effectiveness of employee work. Simultaneously the influence of work conflicts, individual characteristics, and work disciplines has a significant influence on the effectiveness of employee work.
\end{abstract}

Keywords: Conflict of Work, Individual Characteristics, Discipline, Effectiveness

\begin{abstract}
ABSTRAK : Efektifitas bekerja perlu diperhatikan sebab mempunyai efek yang besar terhadap kepentingan organisasi. Efektivitas berarti bahwa tujuan yang telah direncanakan sebelumnya dapat tercapai atau dengan kata lain sasaran tercapai karena adanya proses kegiatan. Efektivitas juga dapat dipandang agar pelaksanaan administrasi lebih mencapai hasil seperti apa yang direncanakan, mencapai sasaran tujuan yang ingin dicapai dan lebih berhasil guna atau tepat guna. Tujuan dari penelitian ini adalah untuk mengetahui pengaruh konflik kerja, karakteristik individu, dan disiplin kerja terhadap efektivitas kerja pegawai di Badan Penanggulangan Bencana Daerah Provinsi Sumatera Utara. Penelitian ini menggunakan pendekatan asosiatif, yaitu penelitian yang dilakukan untuk mengetahui pengaruh atau hubungan antara variabel bebas dengan variabel terikat. Hasil penelitian menunjukkan bahwa secara parsial konflik kerja memiliki pengaruh yang signifikan terhadap efektivitas kerja pegawai. Secara parsial karakteristik individu memiliki pengaruh yang signifikan terhadap efektivitas kerja pegawai. Secara parsial disiplin memiliki pengaruh yang signifikan terhadap efektivitas kerja pegawai.. Secara simultan pengaruh konflik kerja, karakteristik individu, dan disiplin kerja memiliki pengaruh yang signifikan terhadap efektivitas kerja pegawai.
\end{abstract}

Kata Kunci : Konflik Kerja, Karakteristik Individu, Disiplin, efektivitas

\section{Pendahuluan}

Di dalam suatu organisasi, sumber daya manusia adalah aset utama dalam setiap berjalannya suatu kegiatan. Pegawai sebagai sumber daya manusia dalam perusahaan merupakan suatu potensi yang besar untuk menjalankan aktivitas perusahaan. Potensi setiap sumber daya manusia yang ada dalam perusahaan harus dapat dimanfaatkan dengan sebaik-baiknya sehingga mampu memberikan hasil kerja yang optimal sesuai dengan tujuan perusahaan. Kerena tercapainya tujuan yang 
telah ditetapkan oleh perusahaan tidak hanya tergantung pada peralatan modern, sarana dan prasarana yang lengkap, tetapi juga tergantung pada sumber daya manusia / pegawai.

Tanpa peran pegawai meskipun berbagai faktor yang dibutuhkan itu telah tersedia, organisasi tidak akan berjalan. Karena manusia merupakan penggerak dan penentu jalannya suatu organisasi. Oleh karena itu hendaknya organisasi memberikan arahan yang positif demi tercapainya tujuan organisasi.

Pelayanan publik merupakan suatu kegiatan yang harus mendahulukan kepentingan umum, mempermudah urusan publik, mempersingkat waktu pelayanan dan memberikan perhatian kepada publik. Senada dengan itu, Zainun (2005:88) mengemukakan bahwa pelayanan publik adalah kegiatan yang dilakukan oleh seseorang atau sekelompok orang dengan landasan fungsi material melalui sistem, prosedur dan metode tertentu dalam usaha untuk memenuhi kebutuhan orang lain sesuai dengan haknya. Pemenuhan hak orang lain (masyarakat) yang merupakan tujuan dari fungsi pelayanan publik terus ditingkatkan, baik dari sisi kuantitas maupun dari sisi kualitas.

Badan Penanggulangan Bencana Daerah Provinsi Sumatera Utara merupakan sebagai unsur penunjang pemerintah daerah di bidang penanggulangan bencana yang mempunyai tugas membantu kepala daerah dalam menyelenggarakan pemerintahan di bidang penanggulangan bencana dengan cara menyiapkan bahan perumusan kebijakan penanggulangan bencana.

Efektifitas bekerja perlu diperhatikan sebab mempunyai efek yang besar terhadap kepentingan organisasi. Efektivitas berarti bahwa tujuan yang telah direncanakan sebelumnya dapat tercapai atau dengan kata lain sasaran tercapai karena adanya proses kegiatan. Efektivitas juga dapat dipandang agar pelaksanaan administrasi lebih mencapai hasil seperti apa yang direncanakan, mencapai sasaran tujuan yang ingin dicapai dan lebih berhasil guna atau tepat guna.

Menurut Schermerhorn (2010:15), efektivitas kerja merupakan suatu ukuran tentang pencapaian suatu tugas atau tujuan. Efektivitas kerja merupakan salah satu tujuan dari setiap pelaksanaan pekerjaan. Efektivitas kerja dapat dicapai jika pelaksanaan kerja sesuai dengan syarat-syarat yang diperlukan oleh pekerjaan tersebut. Syarat-syarat pelaksanaan kerja sudah ditetapkan dalam setiap perencanaan pekerjaan. Dengan adanya syarat-syarat tersebut, maka pembagian kerja akan lebih mudah dilakukan. Pembagian kerja tentunya terkait dengan kemampuan kerja setiap pegawai atau bagian. Dengan demikian pimpinan akan lebih mudah menyerahkan wewenangnya kepada bawahannya.

Sebagai bagian dari salah satu aset dalam suatu organisasi yang dapat menunjang kelancaran operasional dan membantu organisasi mencapai tujuannya. Maka dari itu diperlukan usaha untuk dapat mengelola sumber daya manusia dengan sebaik mungkin. Salah satu cara yang dapat dilakukan dalam meningkatkan efektifitas kerja pegawainya adalah dengan mengontrol konflik kerja yang ada di lingkungan kerja.

Mangkunegara (2013:155) mengemukakan konflik kerja merupakan suatu pertentangan yang terjadi antara apa yang diharapkan oleh seseorang terhadap dirinya, orang lain, organisasi dengan kenyataan apa yang diharapkannya. Berdasarkan pengertian diatas, konflik kerja adalah ketidaksesuaian antara dua atau lebih anggotaanggota atau kelompok (dalam suatu organisasi) yang harus membagi sumber daya yang terbatas atau kegiatan-kegiatan kerja atau karena kenyataan bahwa mereka mempunyai perbedaan status, nilai atau persepsi..

Berdasarkan dari penelitian yang telah dilakukan oleh Meicha Amelia Putri pada tahun 2017 di PT. Surya Bratasena Plantation Pelalawan, dari hasil penelitiannya menyebutkan bahwa konflik kerja berpengaruh terhadap efektivitas kerja karyawan pada PT. Surya Bratasena Plantation Pelalawan. Dari hasil tersebut maka peneliti merasakan pentingnya pengawasan dan perhatian dari variabel konflik kerja ini dapat mempengaruhi efektivitas kerja pegawai dalam suatu organisasi.

Dari hasil pengamatan awal yang dilakukan oleh peneliti, menyebutkan adanya sikap bersaing yang tidak sehat sesama rekan kerja, ini terlihat seringnya laporan keatasan antar sesama rekan kerja, adanya sikap saling mencari kesalahan pegawai lain dan adanya sikap mengadu domba antar pegawai satu sama lain untuk meyudutkan dan mengadu pihak tertentu.

Karakteristik individu yang mencirikan antara satu orang dengan orang lain berbeda adalah karena masing-masing individu memiliki potensi dan kebutuhan yang berbeda (Gibson, 2000:65). Oleh karena itu pihak manajemen dituntut untuk memahami perilaku individu 
agar selaras dengan tujuan organisasi. Karakteristik individu yang dibawa dalam lingkungan kerja akan berpengaruh terhadap efektivitas kerja pegawainya, sedangkan prestasi kerja individu adalah dasar dari prestasi kerja organisasi. Permasalahan yang muncul pada Badan Penanggulangan Bencana Daerah Provinsi Sumatera Utara adalah pengalaman dari para pegawai, di mana pegawai yang lebih senior akan lebih cepat tanggap dalam menghadapin segala situasi yang terjadi dalam organisasi dibanding dengan pegawai yang baru bergabung. Hal ini didasarkan oleh adanya pemikiran bahwa perbedaan dalam hal kemampuan dan sikap dalam melaksanakan pekerjaan akan berpengaruh terhadap kinerja individu.

Selain itu, dalam melaksanakan pekerjaannya setiap individu harus dapat menempatkan diri dan lingkungan kerjanya dengan baik sehingga akan mempengaruhi individu itu sendiri dapat mencapai keefektifan kerja yang diharapkan. Dalam dunia kerja, biasanya sikap seseorang berkaitan dengan pekerjaannya. Keterkaitan sikap dengan pekerjaan ini akan membuka jalan evaluasi positif atau negatif yang dipegang pegawai mengenai aspek-aspek dari lingkungan kerja mereka. Artinya setiap individu terhadap pekerjaannya mencerminkan pengalaman yang menyenangkan dan tidak menyenangkan dalam pekerjaannya serta harapan-harapan terhadap masa depan. Dalam hal ini karakteristik individu dapat menentukan keberhasilan optimal suatu keefektifan kerja pegawai dalam suatu organisasi.

Berdasarkan hasil penelitian sebelumnya yang telah dilakukan oleh Endra dan kawankawan di tahun 2019, menyebutkan. Karakteristik individu berpengaruh terhadap efektivitas kerja karyawan PT. Kencana Inti Perkasa Medan. Dari hasil penelitian tersebut mengarahkan peneliti mencoba menggunakan variabel ini dalam penelitiannya.

Terlepas dari dua faktor tersebut, faktor yang mempengaruhi keefektifan kerja pegawai berdasarkan pengamatan awal peneliti adalah disiplin kerja pegawai. Dalam mengemukakan pendapatnya Setyaningdyah (2013:145) menyatakan bahwa disiplin kerja merupakan suatu kebijakan yang membuat setiap individu untuk menjadi sosok yang bertanggung jawab dalam mematuhi peraturan yang telah ditetapkan pada lingkungan kerja. Berdasarkan pengertian diatas, disiplin kerja merupakan unsur penting yang dapat menunjang keefektifan kerja pegawai. Apabila disiplin kerja pegawai disuatu organisasi baik, maka efektivitas kerja pegawainya juga baik.

Dari penelitian yang telah dilakukan oleh Eti Dwi Rahayu pada tahun 2006 di Badan Kepegawaian Daerah Kota Semarang, bahwa Berdasarkan hasil penelitian diatas dapat disimpulkan bahwa faktor disiplin kerja dan pengawasan kerja pegawai merupakan faktor yang perlu diperhatikan untuk menciptakan efektivitas kerja bagi pegawai pada Badan Kepegawaian Daerah Kota Semarang. Efektivitas kerja bagi pegawai pada Badan Kepegawaian Daerah Kota Semarang termasuk dalam kategori baik namun masih perlu diperhatikan karena masih belum optimal. Dari hasil tersebut maka peneliti merasakan pentingnya faktor disiplin kerja dapat mempengaruhi efektivitas kerja suatu organisasi. Indikasi penurunan efektivitas kerja pegawai di lingkungan tempat peneliti dapat dibuktikan dengan ketidaktepatan waktu dalam penyelesaian kerja, aturan waktu yang seringkali dilanggar oleh pegawai dan angka keterlambatan yang cukup tinggi.

\subsection{Rumusan Masalah}

Berdasarkan latar belakang masalah tersebut, maka yang menjadi rumusan masalah dalam penelitian ini adalah :

1) Bagaimana pengaruh konflik kerja terhadap efektivitas kerja pegawai di Badan Penanggulangan Bencana Daerah Provinsi Sumatera Utara.

2) Bagaimana pengaruh karakteristik individu terhadap efektivitas kerja pegawai di Badan Penanggulangan Bencana Daerah Provinsi Sumatera Utara.

3) Bagaimana pengaruh disiplin kerja terhadap efektivitas kerja pegawai di Badan Penanggulangan Bencana Daerah Provinsi Sumatera Utara.

4) Bagaimana pengaruh konflik kerja, karakteristik individu dan disiplin kerja terhadap efektivitas kerja pegawai di Badan Penanggulangan Bencana Daerah Provinsi Sumatera Utara.

\subsection{Batasan Masalah}

Agar permasalahan yang dikaji terarah maka permasalahan dibatasi sebagai berikut. Penelitian ini hanya membahas konflik kerja, karakteristik individu dan disiplin kerja terhadap efektivitas kerja pegawai di Badan 
Penanggulangan Bencana Daerah Provinsi Sumatera Utara.

\subsection{Hipotesis}

Berdasarkan rumusan masalah tujuan penelitian, kajian teori, dan kerangka konseptual yang telah dikemukakan diatas, maka rumusan hipotesis penelitian ini dapat dirumuskan sebagai berikut:

1) Konflik kerja berpengaruh postif dan signifikan terhadap efektivitas kerja pegawai di Badan Penanggulangan Bencana Daerah Provinsi Sumatera Utara.

2) Karakteristik individu berpengaruh positif dan signifikan terhadap efektivitas kerja pegawai di Badan Penanggulangan Bencana Daerah Provinsi Sumatera Utara.

3) Disiplin kerja berpengaruh positif dan signifikan terhadap efektivitas kerja pegawai di Badan Penanggulangan Bencana Daerah Provinsi Sumatera Utara.

4) konflik kerja, karakteristik individu dan disiplin kerja berpengaruh positif dan signifikan terhadap efektivitas kerja pegawai di Badan Penanggulangan Bencana Daerah Provinsi Sumatera Utara.

\subsection{Tujuan Penelitian}

Berdasarkan rumusan masalah penelitian sebagaimana diuraikan di atas, maka tujuan yang akan dicapai dalam penelitian ini yaitu untuk menganalisis:

1) Pengaruh konflik kerja terhadap efektivitas kerja pegawai di Badan Penanggulangan Bencana Daerah Provinsi Sumatera Utara.

2) Pengaruh karakteristik individu terhadap efektivitas kerja pegawai di Badan Penanggulangan Bencana Daerah Provinsi Sumatera Utara.

3) Pengaruh disiplin kerja terhadap efektivitas kerja pegawai di Badan Penanggulangan Bencana Daerah Provinsi Sumatera Utara.

4) Pengaruh konflik kerja, karakteristik individu dan disiplin kerja terhadap efektivitas kerja pegawai di Badan Penanggulangan Bencana Daerah Provinsi Sumatera Utara.

\section{Metode Penelitian}

\subsection{Populasi}

Populasi adalah wilayah generalisasi yang terdiri atas objek / subjek yang mempunyai kualitas dan karakteristik tertentu yang ditetapkan oleh peneliti untuk dipelajari kemudian ditarik kesimpulannya. Suharyadi (2004:98). Jadi populasi bukan hanya orang tetapi juga benda-benda alam yang lain. Populasi juga bukan sekedar jumlah yang ada pada objek / subjek yang dipelajari, tetapi meliputi seluruh karakteristik, sifat yang dimiliki objek / subjek itu.

Dari pengertian tersebut, maka dapat disimpulkan bahwa populasi merupakan subjek penelitian dimana pegawai yang akan dikenai perilaku atau dapat dikatakan sebagai keseluruhan objek penelitian yang akan diteliti. Maka yang menjadi populasi dalam penelitian ini adalah pegawai di Badan Penanggulangan Bencana Daerah Provinsi Sumatera Utara yang berjumlah 41 orang.

\subsection{Sampel}

Sampling adalah suatu cara yang ditempuh dengan pengambilan sampel yang benar-benar sesuai dengan keseluruhan obyek penelitian. Teknik pengambilan sampel dalam penelitian ini adalah total sampling. Total sampling adalah teknik pengambilan sampel dimana jumlah sampel sama dengan populasi, Sugiyono (2007:34). Alasan mengambil total sampling karena menurut Sugiyono jumlah populasi yang kurang dari 100 seluruh populasi dijadikan sampel penelitian semuanya.

Dengan teknik penarikan sampel secara total sampling maka sampel dalam penelitian ini adalah 41 orang pegawai, diambil kesulurahan jumlah populasi.

\subsection{Uji Normalitas}

Untuk mengetahui normalitas data yakni dengan melihat penyebaran data (titik) pada sumbu diagonal dari grafik. Menurut Santoso (2004:214), dasar pengambilan keputusan adalah:

1) Jika data menyebar disekitar garis diagonal dan mengikuti arah garis diagonal, maka model regresi memenuhi asumsi normalitas.

2) Jika data menyebar jauh dari garis diagonal dan atau tidak mengikuti arah garis diagonal, maka model regresi tidak memenuhi asumsi normalitas. 


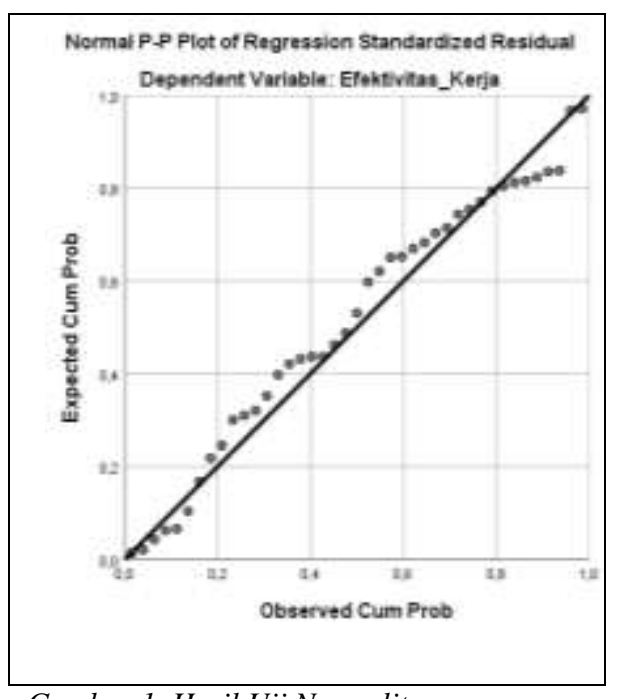

Gambar 1. Hasil Uji Normalitas

Pada output SPSS seperti gambar diatas diketahui bagian normal P-P Plot of Regresion Standardized Residual, dapat dijelaskan bahwa data-data (titik-titik) cenderung lurus mengikuti garis diagonal sehingga data dalam penelitian ini cenderung berdistribusi normal.

\subsection{Uji Heterokedastisitas}

Untuk mengetahui heteroskedastisitas pada data dilakukan dengan cara melihat ada tidaknya pola tertentu pada data yang diolah. Menurut Santoso (2004:208), dasar pengambilan keputusannya adalah:

1) Jika pola tertentu seperti titik-titik yang ada membentuk suatu pola tertentu yang teratur, maka terdapat situasi heteroskedastisitas.

2) Jika tidak ada pola yang jelas, serta titiktitik menyebar diatas dan dibawah angka nol pada sumbu Y, maka tidak terjadi heteroskedastisitas.

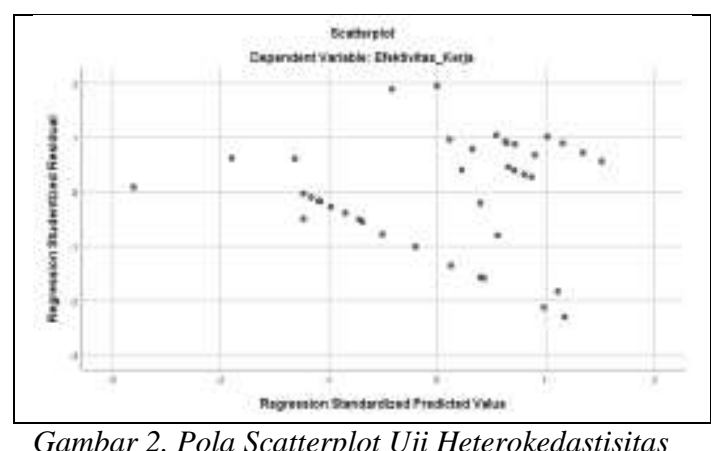

Pola Scatterplot seperti pada gambar diatas, terlihat titk-titik menyebar secara acak, tidak membentuk sebuah pola tertentu yang jelas, serta tersebar baik diatas maupun dibawah angka nol pada sumbu Y. Hal ini berarti tidak terjadi heteroskedastisitas pada model regresi, sehingga model regresi layak dipakai.

\subsection{Uji Multikolinearitas}

Pengujian multikolinearitas dilakukan untuk melihat apakah pada model regresi ditemukan adanya korelasi antara variabel bebas. Jika terjadi korelasi, maka dinamakan terdapat problem multikolinearitas. Cara mendeteksinya adalah dengan melihat nilai Variance Inflation Factor (VIF). Menurut Santoso (2004:203), pada umumnya jika VIF lebih besar dari 5 , maka variabel bebas tersebut mempunyai persoalan multikolinearitas dengan variabel bebas lainnya

Tabel 1. Coefficients

\begin{tabular}{|c|c|c|c|c|c|c|}
\hline \multirow{3}{*}{ Model } & \multicolumn{3}{|c|}{$\begin{array}{c}\text { Tabel 1. Coefficients } \\
\text { Coefficients }^{\mathbf{a}}\end{array}$} & \multirow{3}{*}{$\mathrm{t}$} & \multirow{3}{*}{ Sig. } & \multirow{3}{*}{$\begin{array}{c}\text { Collinearity } \\
\text { Statistics } \\
\text { Tolerance } \mathrm{VIFF}\end{array}$} \\
\hline & \multicolumn{2}{|c|}{$\begin{array}{l}\text { Unstandardized } \\
\text { Coefficients }\end{array}$} & \multirow{2}{*}{$\begin{array}{c}\text { Standardized } \\
\text { Coefficients } \\
\text { Beta }\end{array}$} & & & \\
\hline & $\mathrm{B}$ & Std. Error & & & & \\
\hline (Constant) & 6,719 & 4,984 & & 1,348 & , 186 & \\
\hline Konflik_Kerja &, 120 & , 107 & , 140 & 1,120 & ,270 & 914 \\
\hline 1 Karakteristik_Individu & 148 & 149 &, 139 & ,994 &, 327 &, 734 \\
\hline Disiplin_Kerja & ,506 &, 133 &, 553 & 3,808 & 001 & $680 \vdots 1,471$ \\
\hline
\end{tabular}

Berdasarkan nilai hasil perhitungan dengan SPSS diperoleh data nilai VIF sebesar 1,094; 1,362 dan 1,471 hal ini menunjukkan adanya korelasi yang cukup kuat antara sesama variabel bebas, dimana semua angka VIF berada dibawah 5, hal ini menunjukan tidak terjadi multikolinearitas.

\section{Teknik Analisis Data}

Teknik analisis data yang digunakan adalah regresi linier berganda (multiple linier regression method), untuk mempermudah dalam evaluasi data ini, maka penulis mencari nilai-nilai yang dibutuhkan dengan menggunakan program SPSS berdasarkan tabel 
coefficients pada pengujian multikolinearitas diatas maka diperoleh hasil sebagai berikut: $Y=6,719+0,120 X_{1}+0,148 X_{2}+0,506 X_{3}+$

Persamaan diatas dijelaskan bahwa koefesien $\mathrm{X}_{1}$ (konflik kerja) mempunyai nilai positif yaitu 0,120 hal ini menunjukan bahwa variabel konflik kerja mempunyai pengaruh positif terhadap efektivitas kerja pegawai. Sementara itu pada persamaan diatas bahwa koefesien $\mathrm{X}_{2}$ (karakteristik individu) memiliki nilai positif yaitu 0,148 . Hal ini menunjukan bahwa variabel karakteristik individu mempunyai pengaruh positif terhadap efektivitas kerja pegawai.

Sedangkan berdasarkan persamaan diatas bahwa koefesien $\mathrm{X}_{3}$ (disiplin kerja) memiliki nilai positif yaitu 0,506 . Hal ini menunjukan

bahwa variabel disiplin kerja mempunyai pengaruh positif terhadap efektivitas kerja pegawai di Badan Penanggulangan Bencana Daerah Provinsi Sumatera Utara.

Hal ini berarti semua variabel konflik kerja, karakteristik individu dan disiplin kerja yang saat ini berlaku di Badan Penanggulangan Bencana Daerah Provinsi Sumatera Utara telah mampu meningkatkan efektivitas kerja pegawai dengan nilai yang bervariasi.

\subsection{Pengujian Simultan}

Hasil pengujian hipotesis berpengaruh secara simultan antara disiplin, karakteristik individu dan disiplin kerja terhadap efektivitas kerja pegawai dapat dilihat pada tabel dibawah ini.

ANOVA $^{\mathrm{a}}$

\begin{tabular}{|c|c|c|c|c|c|c|}
\hline \multicolumn{2}{|c|}{ Model } & Sum of Squares & df & Mean Square & $\mathrm{F}$ & Sig. \\
\hline 1 & Regression & 172,399 & 3 & 57,466 & 10,898 &, $000^{\mathrm{b}}$ \\
\hline & Residual & 195,113 & 37 & 5,273 & & \\
\hline & Total & 367,512 & 40 & & & \\
\hline
\end{tabular}

a. Dependent Variable: Efektivitas_Kerja

b. Predictors: (Constant), Disiplin_Kerja, Konflik_Kerja, Karakteristik_Individu

Sumber: Hasil Pengolahan Data Dengan SPSS

Pada tabel diatas terlihat bahwa nilai $\mathrm{F}$ hitung adalah 10,898 dan nilai signifikansi 0,000 . Dengan derajat bebasnya yaitu $\mathrm{df}_{1}=\mathrm{k}-$ $1=4-1=3$ dan $\mathrm{df}_{2}=\mathrm{N}-\mathrm{k}=41-4=37$, maka nilai F-tabel dengan tingkat kepercayaan 95\% $(\alpha: 0,05)$ adalah 2,86 (dari tabel statistik).

Oleh karena itu nilai F-hitung > F-tabel $(\mathbf{1 0 , 8 9 8}>\mathbf{2 , 8 6})$ dan dengan nilai signifikansi $0,000<0,05$ maka Ha diterima dan Ho ditolak berarti hipotesis dalam penelitian ini yaitu konflik kerja, karakteristik individu dan disiplin kerja secara simultan berpengaruh signifikan terhadap efektivitas kerja pegawai di Badan Penanggulangan Bencana Daerah Provinsi Sumatera Utara.

\subsection{Pengujian Parsial}

Untuk mendapatkan nilai t-tabel yang akan menjadi tolok ukur pada pengujian parsial pada tiap-tiap variabel $x$ terhadap variabel y. Dengan derajat bebas pengujian (df) adalah N-k $=41-$ $4=37$. Maka nilai t-tabel pada tingkat kepercayaan 95\% $(\alpha: 0,05)$ adalah 2,026 (dari tabel statistik).

a) Pengaruh Konflik Kerja Terhadap Efektivitas Kerja Pegawai

Dengan bantuan software SPSS, diperoleh hasil t-hitung dengan melakukan pengujian variabel konflik kerja dengan efektivitas kerja pegawai.

Tabel 3. Pengujian Konflik Kerja Terhadap Efektivitas Kerja Coefficients $^{\mathrm{a}}$

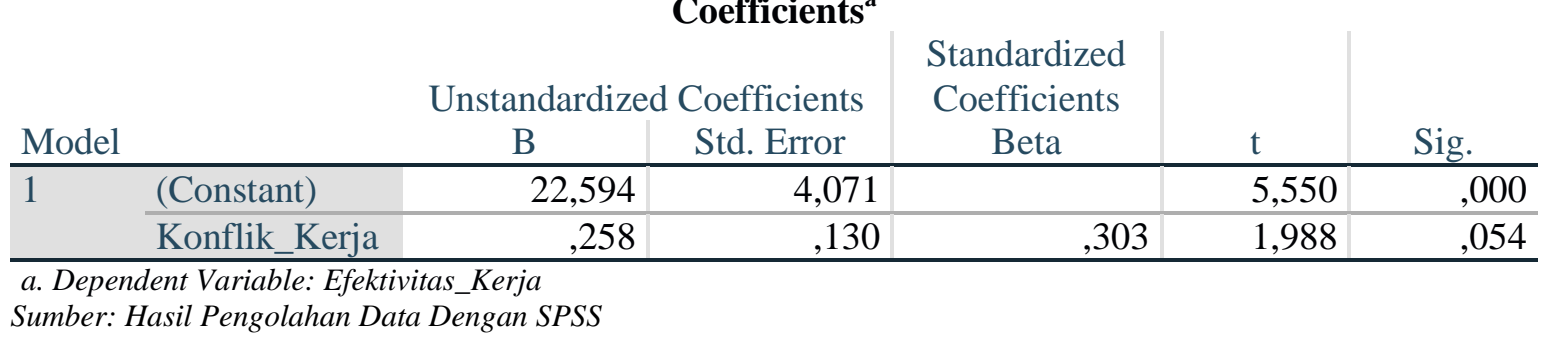


Berdasarkan tabel coefficients diatas diperoleh nilai t-hitung sebesar 1,988 dan dengan nilai sig 0,054 maka nilai t-hitung $<\mathrm{t}$ tabel $(1,988<2,026)$ dan sig $0,054>0,05$, maka dapat disimpulkan Ho diterima dan $\mathrm{Ha}$ ditolak, yang artinya variabel konflik kerja secara parsial tidak ada pengaruh signifikan efektivitas kerja pegawai. b) Pengaruh Karakteristik Individu Terhadap Efektivitas Kerja Pegawai

Sementara iu, pengujian variabel karakteristik individu dengan efektivitas kerja pegawai dengan menggunakan software SPSS, sebagai berikut.

Tabel 4. Pengujian Karakteristik Individu Terhadap Efektivitas Kerja

\section{Coefficients $^{\mathrm{a}}$}

Unstandardized

$$
\text { Coefficients }
$$

Standardized

Coefficients

\begin{tabular}{llr|r|r|r|r} 
Model & & B & Std. Error & Beta & \multicolumn{1}{c}{ t } & \multicolumn{1}{c}{ Sig. } \\
\hline 1 & (Constant) & 16,537 & 4,768 & & 3,469 &, 001 \\
\cline { 2 - 8 } & Karakteristik_Individu &, 456 &, 154 &, 429 & 2,969 &, 005 \\
\hline
\end{tabular}

a. Dependent Variable: Efektivitas_Kerja

Sumber: Hasil Pengolahan Data Dengan SPSS

Berdasarkan tabel coefficients diperoleh nilai t-hitung sebesar 2,969 dengan nilai sig, 0,005 maka nilai t-hitung > t-tabel $(2,969>$ 2,026) dan sig < 0,05, maka dapat disimpulkan Ha diterima dan Ho ditolak, yang artinya variabel karakteristik individu secara parsial ada pengaruh signifikan efektivitas kerja pegawai Badan Penanggulangan Bencana Daerah Provinsi Sumatera Utara.

c) Pengaruh Disiplin Kerja Terhadap Efektivitas Kerja Pegawai

Untuk pengujian disiplin kerja terhadap efektivitas kerja pegawai dengan menggunakan software SPSS, sebagai berikut.

Tabel Error! No text of specified style in document.. Pengujian Disiplin Kerja Terhadap Efektivitas Kerja

Coefficients $^{\mathbf{a}}$

\begin{tabular}{|c|c|c|c|c|c|c|}
\hline \multirow[b]{2}{*}{ Model } & & \multicolumn{2}{|c|}{ Unstandardized Coefficients } & \multirow{2}{*}{$\begin{array}{c}\text { Standardized } \\
\text { Coefficients } \\
\text { Beta }\end{array}$} & \multirow[b]{2}{*}{$\mathrm{t}$} & \multirow[b]{2}{*}{ Sig. } \\
\hline & & B & Std. Error & & & \\
\hline \multirow[t]{2}{*}{1} & (Constant) & 11,898 & 3,406 & & 3,494 &, 001 \\
\hline & Disiplin_Kerja & ,606 &, 110 & 663 & 5,532 & ,000 \\
\hline
\end{tabular}

a. Dependent Variable: Efektivitas_Kerja

Sumber: Hasil Pengolahan Data Dengan SPSS

Berdasarkan tabel coefficients diperoleh nilai t-hitung sebesar 5,532 dan sig. 0,000 maka nilai t-hitung $>$ t-tabel $(\mathbf{5 , 5 3 2}>\mathbf{2 , 0 2 6})$ dan sig. $<\mathbf{0 , 0 5}$, maka dapat disimpulkan Ha diterima dan Ho ditolak, yang artinya variabel disiplin kerja secara parsial ada pengaruh signifikan efektivitas kerja pegawai di Badan Penanggulangan Bencana Daerah Provinsi Sumatera Utara.

\section{Kesimpulan}

Berdasarkan dari hasil pembahasan di atas terkait penelitian mengenai pengaruh konflik kerja, karakteristik individu dan disiplin kerja terhadap efektivitas kerja Pegawai di Badan Penanggulangan Bencana Daerah Provinsi
Sumatera Utara dapat disimpulkan sebagai berikut:

1) Dalam hipotesis penelitian ini yang pertama, secara parsial diperoleh hasil variabel konflik kerja tidak ada pengaruh signifikan terhadap efektivitas kerja pegawai.

2) Hipotesis yang kedua, secara parsial diperoleh hasil variabel karakteristik individu berpengaruh signifikan terhadap efektivitas kerja pegawai.

3) Hipotesis yang ketiga, secara parsial diperoleh hasil variabel disiplin kerja berpengaruh signifikan terhadap efektivitas kerja pegawai. 
4) Hipotesis yang terakhir, secara bersamasama (simultan) diperoleh hasil variabel konflik kerja, karakteristik individu dan disiplin kerja berpengaruh positif dan signifikan terhadap efektivitas kerja pegawai.

\section{DAFTAR PUSTAKA}

As'ad, M. (2004). Psikologi Industri: Seri ilmu Sumber Daya Manusia. Yogyakarta: Liberty.

Barnawi, \& Arifin, M. (2012). Etika dan Profesi Kependidikan. Jogjakarta: Ar-ruzz Media.

Denison, D. R. (2010). Corporate Culture And Organizational Effectiveness.

Endra, J. L., Tarigan, I., \& Syawaluddin. (2019). Analisis Pengaruh Lingkungan Kerja dan Karakteristik Individu Terhadap Efektivitas Kerja Karyawan PT. Kencana Inti Perkasa Medan. Jurnal Bisnis Kolega.

Gibson, J. L. (2000). Organisasi, Perilaku, Struktur dan Proses. Edisi Ke-5. Cetakan $\mathrm{Ke}$-3. Jakarta: Erlangga.

Gibson, J. L., \& al, e. (2006). Organisasi dan Manajemen, Perilaku, Struktur dan Proses. DIterjemahkan oleh Djoerban Wahid. Jakarta: Erlangga.

Hamali, A. Y. (2016). Pemahaman Manajemen Sumber Daya Manusia. Yogyakata: Center for Academic Publishing Service.

Handoko, T. H. (2012). Manajemen Personalia dan Sumber Daya Manusia. Yogyakarta: BPFE.

Hasibuan, M. S. (2010). Manajemen Sumber Daya Manusia. Jakarta: PT. Bumi Aksara.

Kreitner, \& Kinicki. (2009). Perilaku Organisasi. Edisi Ke-5. Jakarta: Salemba Empat.

Lubis, A. F., \& Syahputra, A. (2008). Pedoman Penulisan Proposal dan Tesis. Medan: Program Magister Akuntansi Sekolah Pascasarjana USU.

Mangkunegara, P. A. (2013). Manajemen Sumber Daya Manusia Perusahaan. Bandung: Remaja Rosda Karya.

Marwansyah. (2016). Manajemen Sumber Daya Manusia. Bandung: Alfabeta.

Purnomo, R., \& Lestari, S. (2010). Pengaruh Kepribadian, Self-Efficacy dan Locus Of Control Terhadap Persepsi Kinerja Usaha Skala Kecil dan Menengah. Jurnal Bisnis dan Ekonomi, 144-160.

Putri, A. M. (2017). Pengaruh Semangat Kerja Dan Konflik Kerja Terhadap Efektivitas
Kerja Karyawan di PT. Surya Bratasena Plantation Pelalawan. JOM Fecon.

Rahayu, E. D. (2006). Pengaruh Disiplin Kerja dan Pengawasan Kerja Terhadap Efektivitas Kerja Pegawai Pada Badan Kepegawaian Daerah Kota Semarang. Semarang.

Rahman, A. A. (2013). Psikologi Sosial. Jakarta: PT. Raja Grafindo Persada.

Rivai, V., \& Sagala, E. J. (2009). Manajemen Sumber Daya Manusia Untuk Perusahaan dari Teori ke Praktik. Jakarta: PT. Raja Grafindo.

Rivai, V., \& Sagala, E. J. (2013). Manajemen Sumber Daya Manusia Untuk Perusahaan. Jakarta: Rajawali Pers.

Robbins, S. P. (2006). Perilaku Organisasi. Edisi kesepuluh. Jakarta: Gramedia.

Robbins, S. P., \& Judge, T. A. (2008). Perilaku Organisasi. Edisi Ke-12. Jakarta: Salemba Empat.

Schermerhorn, J. J. (2010). Manajemen. Diterjemahkan oleh Karta Wiguna. Yogyakarta: Andi Offset.

Setyaningdyah, E., Nimran, K. U., \& Thoyib, A. (2013). The Effects of Human Resource Competence, Organisational Commitment and Transactional Leadership on Work Discipline, Job Satisfaction and Employee's Performance. Interdisciplinary Journal Of Contemporary Research In Business, 140-153.

Siagian, S. P. (2012). Manajemen Sumber Daya Manusia. Jakarta: Bumi Aksara.

Sinambela, L. P. (2012). Kinerja Pegawai Teori Pengukuran dan Implikasi. Yogyakarta: Graha Ilmu.

Soetopo, H. (2012). Perilaku Organisasi. Bandung: PT. Remaja Rosdakarya.

Subyantoro, A. (2009). Karakteristik Individu, Karakteristik Perkerjaan, Karakteristik Organisasi dan Kepuasan Kerja Pengurus yang Dimediasi oleh Motivasi Kerja (Studi pada pengurus KUD di Kabupaten Sleman. Jurnal Manajemen dan Kewirausahaan, 11-79.

Sugiyono. (2007). Statistika Untuk Penelitian. Bandung: Alfabeta.

Sugiyono. (2014). Metode Penelitian Pendidikan Pendekatan Kuantitatif, Kualitatif, dan $R \& D$. Bandung: Alfabeta.

Suharyadi, P. S. (2004). Statistika Untuk Ekonomi dan Keuangan Modern, Buku Kedua. Jakarta: Bumi Aksara. 
Sule, E. T., \& Saefullah, K. (2005). Pengantar Manajemen. Edisi pertama. Jakarta: Prenada Media.

Sutarto. (2012). Dasar-dasar Kepemimpinan Administrasi. Edisi Ke-8. . Yogyakarta: Gadjah Mada University Press GMUP.

Sutrisno, E. (2009). Manajemen Sumber Daya Manusia. Edisi Pertama. Jakarta: Kencana Prenada Media Group.

Sutrisno, E. (2011). Manajemen Sumber Daya Manusia. Jakarta: Kencana.

Thoha, M. (2010). Kepemimpinan Dalam Manajemen. Jakarta: PT. Raja Grafindo Persada.

Triton. (2006). SPSS 12.00 Terapan Riset Statistik Parametrik. Yogyakarta: Andi.

Umam, K. (2010). Perilaku Organisasi. Bandung: Pustaka Setia.

Veithzal, R. (2011). Manajemen Sumber Daya Manusia untuk Perusahaan, dari Teori ke Praktik. Jakarta: Raja Grafindo Persada.

Winardi. (2004). Manajemen Perilaku Organisasi. Jakarta: Prenada Media Kencana.

Zainun, B. (2005). Manajemen Dan Motivasi. Jakarta: Balai Aksara. 